\title{
Violacein induces cell death by triggering mitochondrial membrane hyperpolarization in vitro
}

Angélica Maria de Sousa Leal', Jana Dara Freires de Queiroz', Silvia Regina Batistuzzo de Medeiros', Tatjana Keesen de Souza Lima ${ }^{2}$ and Lucymara Fassarella Agnez-Lima ${ }^{1 *}$

\begin{abstract}
Background: Violacein is a purple pigment from Chromobacterium violaceum that possesses diverse biological and pharmacological properties. Among these, pro-oxidant and antioxidant activities have been suggested. However, the cytotoxic mechanisms induced by violacein are poorly understood and the improvement in knowledge regarding these cell death mechanisms will be useful to develop new therapeutic approaches. Considering this, in our work, we investigated the pro-oxidant effects of violacein in non-tumor (CHO-K1 and MRC-5) and tumor (HeLa) cell lines, searching for a better understanding of reactive oxygen species (ROS) production and cell death induction.
\end{abstract}

Results: Cytotoxicity induced by violacein was observed in the three cell lines; however, MRC-5 and HeLa cells were shown to be more sensitive to violacein treatment. Although punctual alterations in the antioxidant apparatus and increase in oxidative stress biomarkers was observed in some violacein concentrations, no association was found between increased oxidative stress and induction of cell death. However, the increase of mitochondrial membrane potential was observed.

Conclusions: In fact, the increase of mitochondrial membrane potential in MRC-5 and HeLa cells suggests that mitochondrial membrane hyperpolarization might be the main cause of cell death triggered by violacein.

Keywords: Violacein, Chromobacterium violaceum, Oxidative stress, Cytotoxicity, Mitochondrial membrane potential

\section{Background}

Violacein is a purple pigment produced by Chromobacterium violaceum, a betaproteobacteria commonly found in tropical and sub-tropical regions. This pigment has attracted interest owing to its several biological and pharmacological activities, including antibiotic [1-3], antitumoral [4-6], antileishmanial [7], antiviral [8, 9], antiprotozoal and antiparasitary [10-12], immunomodulatory, analgesic and antipyretic [13], anti-diarrheal and ulcerprotective effects [14].

The antioxidant activity of violacein has been studied in distinct models, as a scavenger of nitrogen reactive species, 2,2-diphenyl-1-picrylhydrazyl (DPPH) radicals

\footnotetext{
* Correspondence: Ifagnez@ufrnet.br

${ }^{1}$ Departamento de Biologia Celular e Genética, Universidade Federal do Rio Grande do Norte, CEP 59072-970, Natal, RN, Brazil

Full list of author information is available at the end of the article
}

and hydroxyl radicals and by inhibiting lipid peroxidation [15]. Despite this in vitro antioxidant potential, ROS production mediated by violacein, followed by activation of caspase-3, release of cytochrome c, calcium release to the cytosol and apoptotic cell death, were reported in colon cancer Caco-2 cells [16]. Moreover, the cytotoxicity toward EAT cells mediated by ROS production and the decrease in intracellular GSH levels were observed after treatment with violacein [5].

Concerning these two contrasting effects (antioxidant and pro-oxidant) and the limited number of cell lines evaluated to date, the present study was carried out to investigate the pro-oxidant effects of violacein in nontumor and tumor cell lines, aiming to perform a comparative analysis of the cellular responses and a better understanding of the mechanisms involved with cell

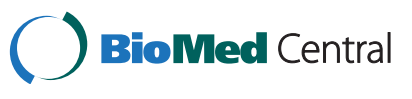

(c) 2015 Leal et al. This is an Open Access article distributed under the terms of the Creative Commons Attribution License (http://creativecommons.org/licenses/by/4.0), which permits unrestricted use, distribution, and reproduction in any medium, provided the original work is properly credited. The Creative Commons Public Domain Dedication waiver (http:// creativecommons.org/publicdomain/zero/1.0/) applies to the data made available in this article, unless otherwise stated. 
death that may be useful for developing new therapeutic products.

\section{Results}

Violacein induced loss of cell viability and cell death by necrosis or apoptosis

Thecell viability data obtained using the Trypan blue dye exclusion method showed that, after incubation with violacein for $24 \mathrm{~h}, \mathrm{MRC}-5$ and HeLa cells exhibited nearly $60 \%$ of cell viability when exposed to $6 \mu \mathrm{M}$ violacein. However, a weaker cytotoxicity was observed in CHO-K1 cells (Fig. 1a). As shown in Fig. 1b, exposure to $3 \mu \mathrm{M}$ violacein for $48 \mathrm{~h}$ caused an approximately $50 \%$ decrease in cell viability in all of the cell lines tested, with MRC-5 and HeLa cells being more sensitive to the treatment.

Annexin $\mathrm{V}$ is a recombinant phosphatidylserine-binding protein that specifically interacts with phosphatidylserine residues and can be used for the detection of apoptosis. Cells treated with violacein were stained with Annexin-V and PI for necrosis detection $[17,18]$. In all of the concentrations tested, violacein could induce necrosis in $\mathrm{CHO}-$ $\mathrm{K} 1$ cells due to the significant increase $(p<0.001)$ in AnnexinV $V^{-} / \mathrm{PI}^{+}$and Annexin $\mathrm{V}^{+} / \mathrm{PI}^{+}$cells (Fig. 2a). Although Annexin $\mathrm{V}^{+} / \mathrm{PI}^{+}$is characteristic of both late apoptotic or early necrotic cells, the low percentage of Annexin $\mathrm{V}^{+} / \mathrm{PI}^{-}$labeling, which is characteristic of early apoptotic cells, might be an indication that cells presenting double staining $\left(\mathrm{AnnexinV}^{+} / \mathrm{PI}^{+}\right)$are undergoing necrosis. For MRC- 5 cells, labeling features of both necrotic and apoptotic cells were observed with all of the concentrations tested (Fig. 2b). However, the percentage of necrotic cells was significant with $6 \mu \mathrm{M}$ violacein, suggesting that necrosis might be the predominant cell death mechanism. By contrast, the results obtained with HeLa cells showed that most of the cells displayed markers of early and late apoptosis when exposed to violacein (Fig. 2c). As observed in the Trypan blue dye exclusion assays (Fig. 1) and in the flow cytometric analysis, the decrease in cell viability was not continuously observed, as higher concentrations were tested. However, there were differences between given concentrations. Fig. 2a-c also shows the dot plots of Annevin V/FITC against PI (panels at right).

\section{Effects on the antioxidant apparatus}

As demonstrated in Fig.3a, in CHO-K1 cells, violacein at 1.5-6 $\mu \mathrm{M}$ led to an increase in SOD activity. Regarding to MRC-5 cells, a significant increase in SOD levels was observed specifically in cells exposed to violacein at $3 \mu \mathrm{M}$, but a decreased SOD activity was observed when cells were submitted to $6 \mu \mathrm{M}$. In fact, the decrease was observed either for HeLa cells submitted to violacein at $6 \mu \mathrm{M}$ and one possible explanation for this decrease might be violacein cytotoxicity at this concentration. Considering the catalase assays, not even the highest concentration tested caused significant changes in enzymatic activity in CHO-K1 and HeLa cells. In contrast, in MRC-5 cells, violacein at $1.5 \mu \mathrm{M}$ lead to the inhibition of catalase activity, but it is not clear why this occurs (Fig. 3b). A significant decrease in GSH levels was observed in HeLa cells exposed to violacein at 0.75, 1.5 and $6 \mu \mathrm{M}$ (Fig. 3c).

\section{Oxidative stress biomarker detection}

A significant increase in the protein carbonyl levels was observed exclusively in CHO-K1 cells exposed to 1.5$3 \mu \mathrm{M}$ violacein (Fig. 4a). Regarding to lipid peroxidation markers, increased lipid hydroperoxide levels were observed in MRC- 5 cells exposed to $3 \mu \mathrm{M}$ violacein (Fig.4b). In contrast, violacein was not able to increase the levels of 8-isoprostanes in any concentration tested (Fig. 4c). Interestingly, a decrease in 8-oxoguanine (8-oxoG, a DNA oxidized lesion) levels was observed in CHO-K1, MRC-5 and Hella cells exposed to 1.5-6 $\mu \mathrm{M}$ violacein (Fig. 4d).
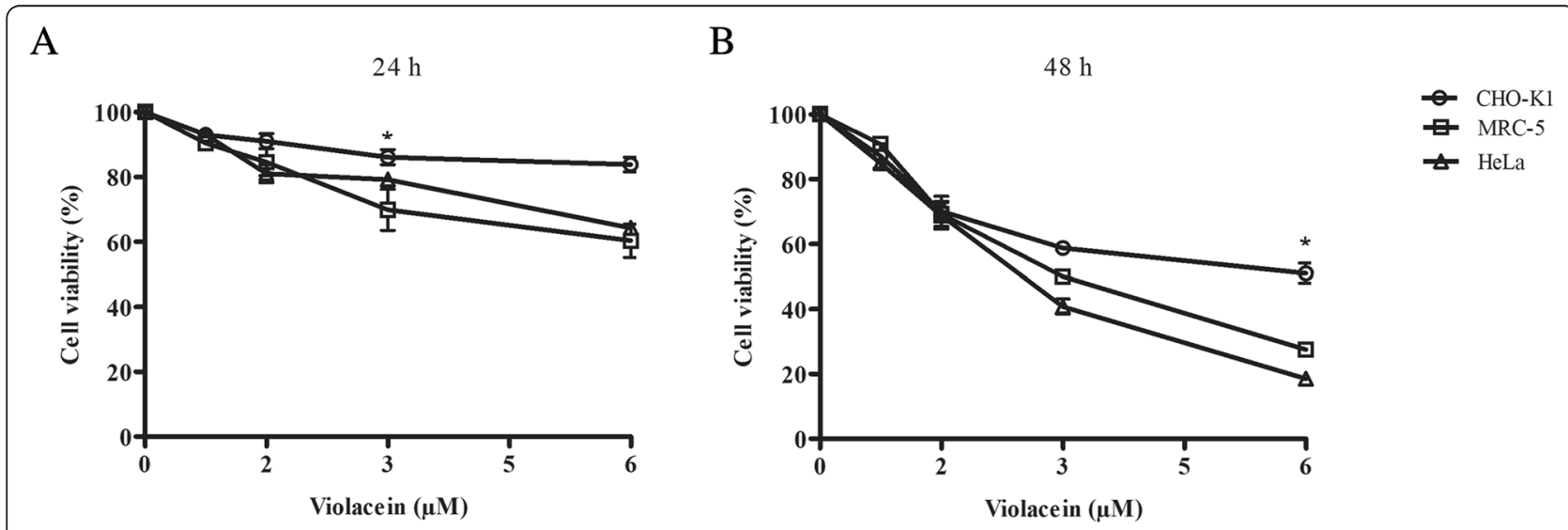

Fig. 1 Effects of violacein on the cell viability of CHO-K1, MRC-5 and HeLa cells, as determined by the Trypan blue dye exclusion method after exposure to $0.75-6 \mu \mathrm{M}$ violacein for 24 (a) and (b) $48 \mathrm{~h}$. The viability of untreated cells was expressed as $100 \%$ 


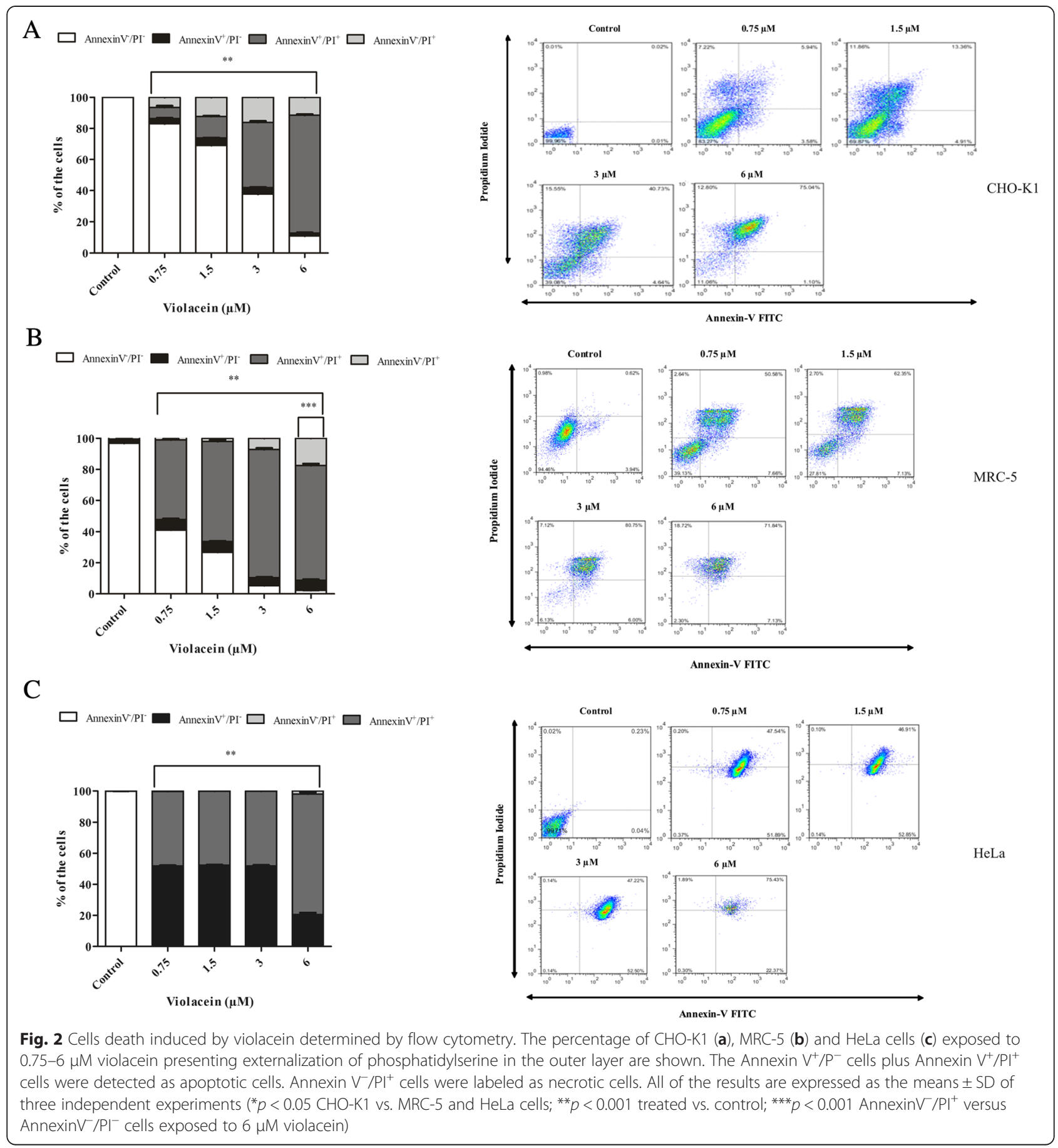

Effect of violacein on mitochondrial membrane potential Considering that $\mathrm{RH} 123$ uptake is proportional to the mitochondrial transmembrane potential, the results shows that violacein leads to the increase of the mitochondrial membrane potential (Fig. 5) in MRC-5 and HeLa cells at all of the concentrations tested. By contrast, in CHO-K1 cells, no significant changes in the membrane potential were detected. These data suggest that the cytotoxicity induced by violacein may be due to mitochondrial damage that leads to membrane hyperpolarization, triggering cell death. However, the cytotoxicity of violacein in $\mathrm{CHO}-\mathrm{K} 1$ cells may be related to a violacein cell-type specific mechanisms, other than the induction of mitochondrial membrane hyperpolarization.

\section{Discussion}

In general, the cytotoxicity of violacein for non-tumor cells occurs in the range of $5-10 \mu \mathrm{M}[4,5,19]$, while the 


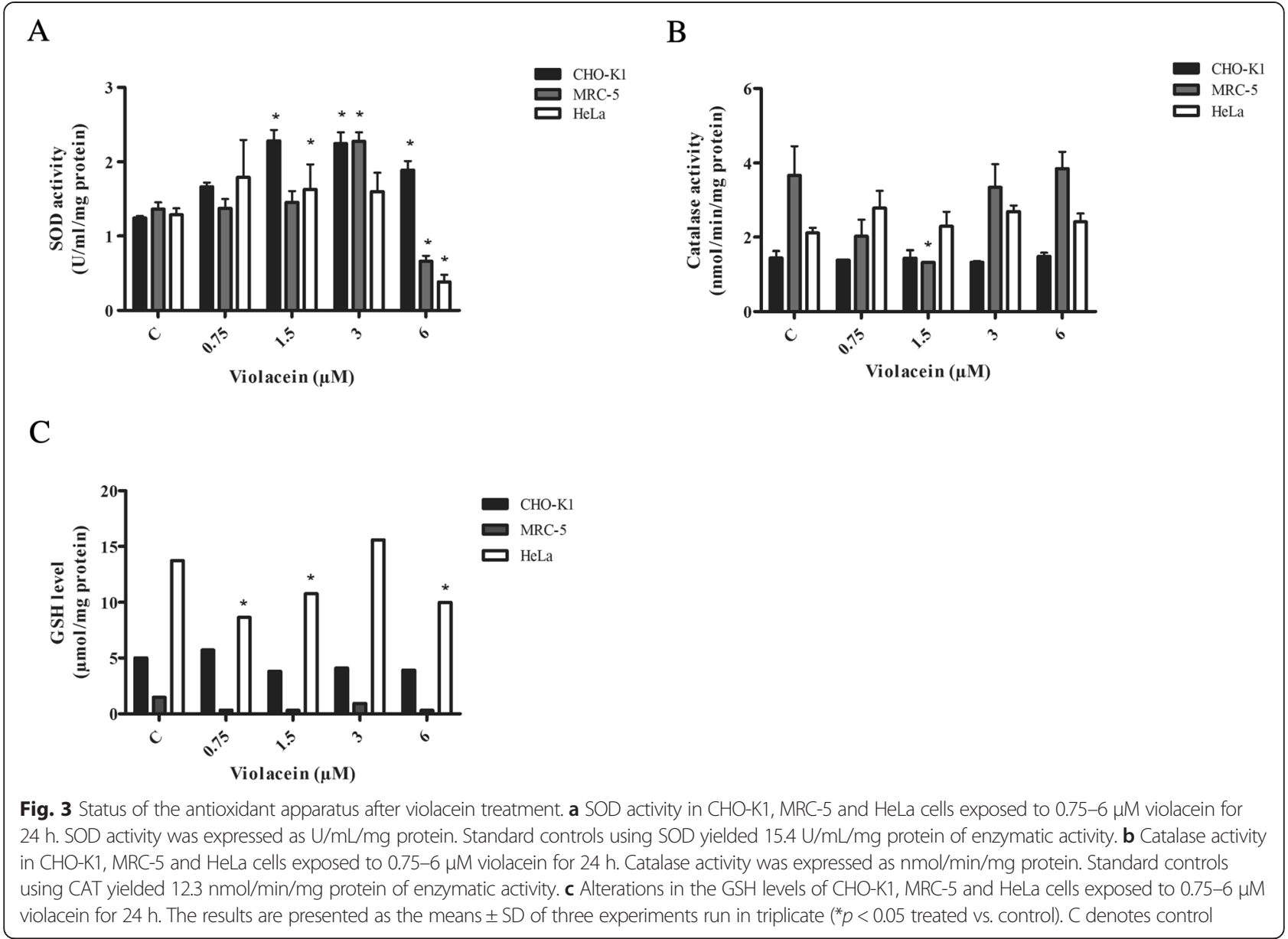

cytotoxicity for tumor cells is observed in the range of 1-5 $\mu \mathrm{M}[5,16,20]$, findings that are in agreement with the data obtained in our work. Concerning tumor cells, the most promising results were obtained with the cell lines MOLT-4 (leukemia), NCI-H460 (lung cancer) and KM12 (colon cancer), in which very low violacein concentrations $(0.03-0.06 \mu \mathrm{M})$ showed cytotoxicity [4]. Moreover, in melanoma 92.1andOCM-1 cells, the cytotoxicity was exhibited in the range of $1.69-3.69 \mu \mathrm{M}$ [20]. In our work, violacein cytotoxicity was highest at $6 \mu \mathrm{M}$. Indeed, variations in violacein cytotoxicity are observed depending on the cell type, indicating the occurrence of violacein cell-type-specific mechanisms $[5,16]$.

Previously, the cytotoxicity induced by violacein was attributed to ROS generation $[5,16]$, despite its antioxidant activity observed in vitro [15]. Here, we analyzed the induction of antioxidant enzymes and occurrence of oxidative stress biomarkers in cells treated with violacein to identify the association between oxidative stress and cell death. We observed that certain concentrations of violacein induced SOD activity in CHO-K1 and MRC-5 cells, but a dose-dependent response was not obtained. Concerning catalase activity, significant differences were not observed. Interestingly, catalase activity was reduced in MRC-5 cells after the treatment with $1.5 \mu \mathrm{M}$ violacein, but the cause of this inhibition is unclear. Despite the relationship between SOD and catalase activities [21], the non-concomitant increase in the activity of these enzymes has been demonstrated [22], as observed in our work.

According to Bromberg et al. [5], treatment with violacein $(2-5 \mu \mathrm{M})$ led to the reduction of GSH levels in EAT cells. Similarly, in our work, a significant decrease in GSH levels was observed in HeLa cells treated with specific concentrations of violacein. However, the GSH depletion in HeLa cells may be caused by mechanisms other than an excessive level of ROS. In fact, we observed the induction of SOD and occurrence of oxidative stress biomarkers for certain concentrations of violacein (Figs. 3 and 4). However, these data do not support the role of ROS in the cell death observed after treatment because dose-dependent responses were not observed.

Interestingly, the increase of membrane potential was detected even at the lowest violacein concentration tested, suggesting that violacein toxicity is associated with mitochondria damage. Comparing these results with the 


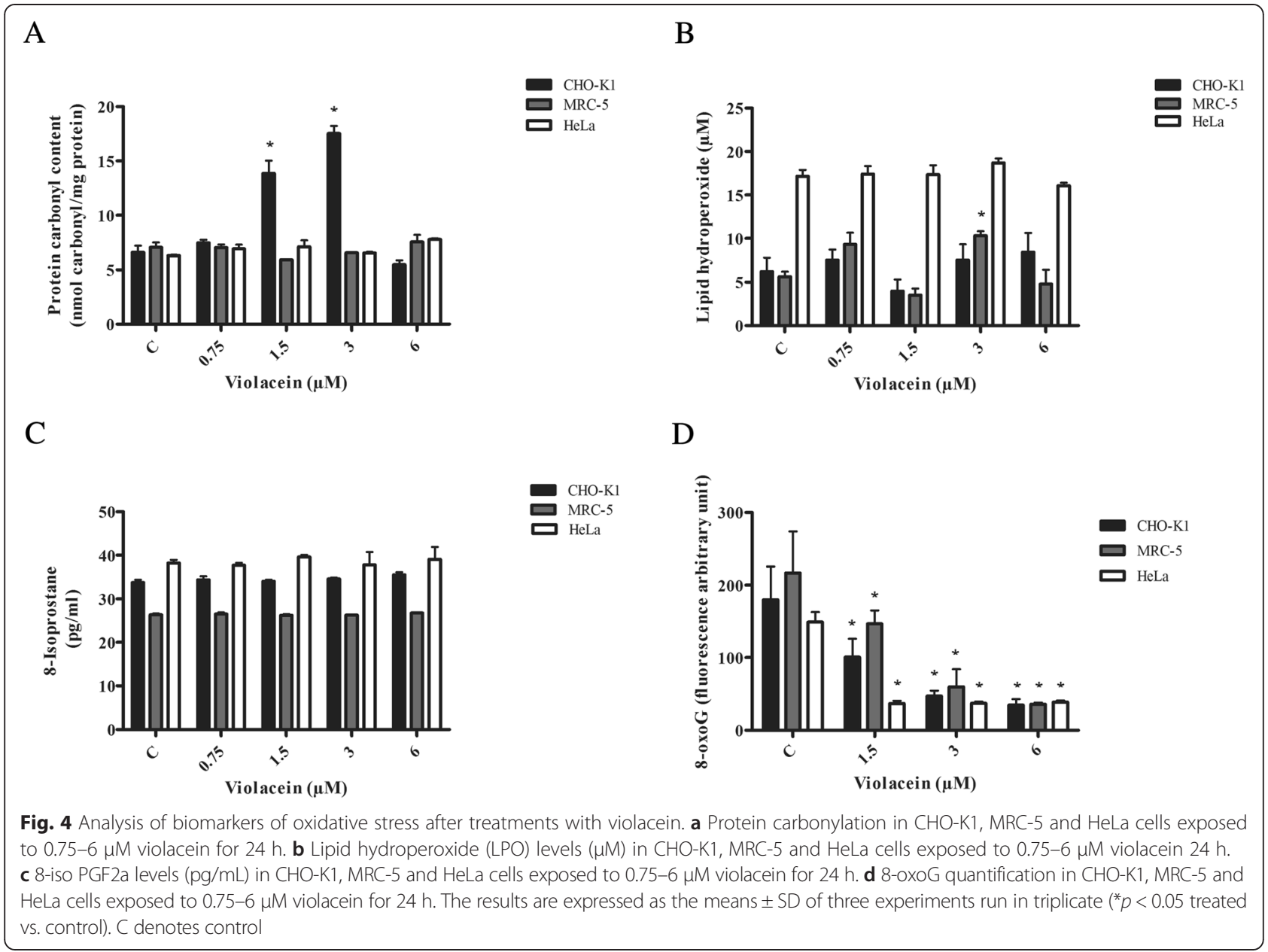

cytotoxicity induced by violacein, the co-occurrence of cytotoxicity and the increase of mitochondrial membrane potential might be indicative that cytotoxicity caused by violacein occurs through the mitochondrial pathway. However, the differences observed in cell viability and the

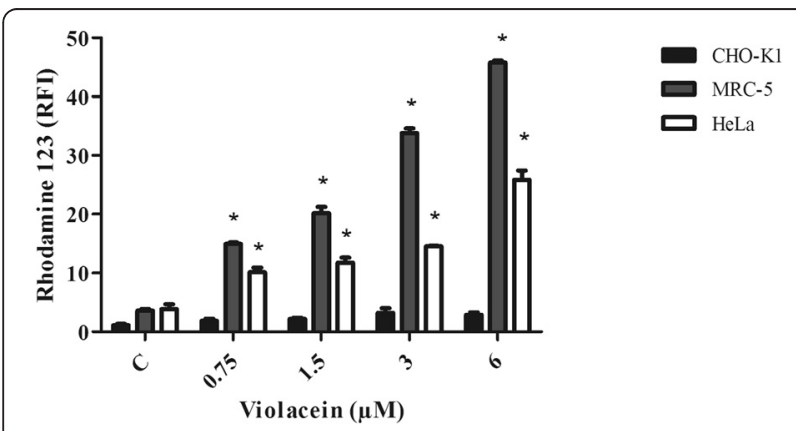

Fig. 5 Effects of violacein on the mitochondrial membrane potential of CHO-K1, MRC-5 and HeLa cells. Cells were stained with Rhodamine 123 and analyzed by flow cytometry in the FL-1 (FITC) channel. The results are expressed as the means \pm SD of three experiments run in triplicate $\left({ }^{*} p<0.05\right.$ treated vs. control). C denotes control proportions of cells in apoptosis and/or necrosis (Fig. 2) suggest the occurrence of cell-type-specific mechanisms. Previous study [23] carried out with 2,237 fibrosarcoma cells treated for $48 \mathrm{~h}$ with PVP, a violacein-like pigment from the Antarctic Janthinobacterium sp bacteria, showed that the treatment induced the disruption of the mitochondrial membrane potential and occurrence of apoptosis via the mitochondrial pathway. Furthermore, another cell death mechanism has been suggested by Queiroz et al. [6], showing the effect of violacein on TF1 leukemia cells by the induction of cellular suicide, by a mechanism involving the endoplasmic reticulum, Golgi linearization and 'horseshoe-shaped' nuclei. Melo et al. demonstrated that the treatment of HL60 cells with violacein induced cytotoxic effects and cell differentiation, which may be related to alterations in phospholipid asymmetry and changes in mitochondrial polarization [24]. In addition, the violacein-dependent association of TRAF2 with the TNF receptor was observed by co-immunoprecipitation assays, suggesting that apoptosis of HL60 cells mediated by violacein occurs by specific activation of TNF receptor 1 [25]. 
Mitochondrial dysfunction has been shown to participate in the induction of cell death and has been suggested to be central to the apoptotic pathway [26]. Indeed, early hyperpolarization of mitochondrial membrane has been reported as an event that occurs in several cell death pathways [27-29]. Collectively, the results suggest that violacein induces cell death of both MRC-5 and HeLa cells through the hyperpolarization of the mitochondrial membrane potential, acting through a mitochondrial pathway. By contrast, in CHO-K1 cells, the cytotoxic effects of violacein may be related to other mechanisms specific for this cell line.

\section{Conclusion}

In conclusion, although violacein induced SOD activity and increased certain oxidative stress biomarkers, oxidative stress does not seem to be the major cause of cell death observed after the treatment because dose-dependent responses were not observed. Interestingly, in MRC-5 and HeLa cells, the hyperpolarization of the mitochondrial membrane potential may be related to cell death triggered by violacein. Due to the pharmacological potential of violacein, a better understanding of the cell death mechanisms induced by this compound will be useful to develop new therapeutic approaches.

\section{Methods}

\section{Violacein}

Purified violacein (3-(1,2-dihydro-5-(5-hydroxy-1H-indol3-yl)-2-oxo-3H-pyrrol-3-ilydene)-1,3-dihydro-2H-indol-2one) $[9,10,30]$ was kindly provided by Dr. Regina Vasconcellos Antonio (BQM-UFSC, Brazil). Violacein was dissolved in DMSO (dimethyl sulfoxide; Merck, Germany) and added to the cultured medium to a final DMSO concentration of less than $0.1 \%$ ( $\mathrm{vol} / \mathrm{vol})$. The violacein was stored at $4{ }^{\circ} \mathrm{C}$, protected from light and diluted in fresh cell culture medium prior to use.

\section{Cytotoxicity assays}

To evaluate the cytotoxic effects of violacein, MRC-5 (human fetal lung fibroblast), CHO-K1 (Chinese hamster ovary) and HeLa (human cervical adenocarcinoma) cells were cultured in flasks containing DMEM medium (Gibco, USA) supplemented with $10 \%$ fetal bovine serum (FBS) and antibiotics (100 U/mL of penicillin and $100 \mu \mathrm{g} / \mathrm{mL}$ of streptomycin) (Gibco) in a $\mathrm{CO}_{2}$ incubator at $37^{\circ} \mathrm{C}$. For the cytotoxicity assays, cells were seeded $\left(3 \times 10^{5}\right.$ cells $\mathrm{mL}^{-1}$ /well) in 6-well plates for $24 \mathrm{~h}$ and exposed to $0.75-6 \mu \mathrm{M}$ violacein for 24 and $48 \mathrm{~h}$. Next, the cell monolayers were washed three times with cold PBS, $\mathrm{pH}$ 7.4, harvested using a $1 \times$ trypsin-EDTA solution (Gibco) and resuspended in fresh DMEM medium. Cell viability was measured using the Trypan blue dye exclusion method [31].
To evaluate the occurrence of cell death by apoptosis or necrosis, the cells were treated as described above. After the treatments, cells were briefly washed in cold PBS, pH 7.4, and collected by trypsinization. The cell pellets were resuspended in a binding buffer $\left(1 \times 10^{6} / \mathrm{mL}\right.$ cell density) and stained with $5 \mu \mathrm{L}$ of Annexin V-FITC and $5 \mu \mathrm{L}$ of propidium iodide (PI), as indicated in the FITC Annexin V Apoptosis Detection Kit I (Catalog No.556547; BD Pharmingen ${ }^{\mathrm{TM}}$, USA). The cells were incubated in the dark at room temperature for $15 \mathrm{~min}$ and analyzed on a FACSCANTO II flow cytometry system (BD Biosciences, USA). For each sample, 30,000 events were collected, and the analysis was performed using Flowjo 7.6.4 software (Treestar Ashland, USA).

\section{SOD and Catalase activities}

Violacein-exposed cells were washed twice by resuspension in cold PBS, pH 7.4, and the cell pellets were sonicated in a cold buffer (20 mM HEPES buffer (Amresco, USA), pH 7.2, containing 1 mM EGTA (ethylene glycol tetraacetic acid; Sigma-Aldrich, USA), $210 \mathrm{mM}$ mannitol and $70 \mathrm{mM}$ sucrose) using the Ultrasonic processor (Sonic vibraCell $^{\mathrm{TM}}$, Canada). SOD activity was evaluated as indicated in the Superoxide Dismutase Assay Kit (Catalog No.706002; Cayman Chemical Company, USA). For catalase activity measurements, cells were treated, washed twice in PBS, pH 7.4, sonicated in a cold buffer (50 mM potassium phosphate, $\mathrm{pH}$ 7.0, containing $1 \mathrm{mM}$ EDTA) and tested for enzymatic activity as indicated in the Catalase Assay Kit (Catalog No.707002; Cayman Chemical Company). Protein quantification was determined by the Bradford assay [32].

\section{GSH levels}

To determine whether violacein can reduce cellular GSH levels, cells were washed twice in cold PBS, pH 7.4, and the cell pellets were homogenized in a cold buffer $(50 \mathrm{mM}$ MES, pH 7.0, containing $1 \mathrm{mM}$ EDTA). The supernatant was stored on ice and deproteinized using metaphosphoric acid and triethanolamine at $0.1 \mathrm{~g} / \mathrm{mL}$ and $4 \mathrm{M}$, respectively. Deproteinized samples were used to assay total GSH (both oxidized and reduced forms) as indicated in the Glutathione Assay Kit (Catalog No. 703002, Cayman Chemical Company). The normalization was based the protein content of samples as determined by the Bradford assay [32].

\section{Membrane lipid peroxidation assays: Lipid hydroperoxides (LPOs) and 8-Isoprostanes (8-iso PGF2a)}

After incubation with violacein, cells were washed twice by resuspension in cold PBS, pH 7.4, and the cell pellets were sonicated in HPLC-grade water. The LPOs and (8-iso PGF2a) were extracted and quantified as indicated in the Lipid Hydroperoxide Assay Kit (Catalog No. 705003; Cayman Chemical Company) and 8-Isoprostane 
EIA Kit (Catalog No.516351, Cayman Chemical Company), respectively.

\section{Protein carbonyls}

Total protein was extracted as described in [33] with modifications. Cells were centrifuged, collected in cold PBS and incubated in lysis buffer $(50 \mathrm{mMTris}-\mathrm{HCl}, 150 \mathrm{mM}$ $\mathrm{NaCl}, 0.1 \%$ SDS, HPLC-ultrapure grade water, protease inhibitors (1:100) (Merck) and $25 \mathrm{U}$ DNase benzonase (Merck) for $20 \mathrm{~min}$ at $4{ }^{\circ} \mathrm{C}$. After lysis, the supernatants containing total protein extracts were recovered and the proteins quantified by the Bradford method [32]. After that, protein carbonyls were quantified as proposed by Hawkins et al. [34].

\section{Detection of 8-oxoguanine}

Initially, cells at $10^{5}$ cells $\mathrm{mL}^{-1} /$ well density were seeded in 96-well plates for $24 \mathrm{~h}$ and treated with violacein. Next, cells were fixed in methanol at $-20{ }^{\circ} \mathrm{C}$ (Labsynth) for $20 \mathrm{~min}$, washed in cold PBS and permeabilized with PBS containing $0.1 \%$ Triton X-100 (USB corporation). Nonspecific ligation events were blocked by incubating cells in PBS containing $10 \%$ FBS for $1 \mathrm{~h}$. Finally, the cells were incubated in the dark at $37{ }^{\circ} \mathrm{C}$ in PBS containing FITC-avidin (Sigma-Aldrich) (1:200 dilution) for $1 \mathrm{~h}$. After four washes in PBS containing 10 \% FBS, fluorescence was detected at $485 \mathrm{~nm}$ excitation and 535 emission (GloMax ${ }^{\circ}$-Multi Detection System; Promega, USA).

\section{Mitochondrial dysfunction evaluation}

Changes in the mitochondrial transmembrane potential were assayed through the incorporation of Rhodamine 123 (Rh123) (Sigma-Aldrich), a mitochondrial-specific cationic fluorescent dye. After treatments, cells were resuspended at $1 \times 10^{5} / \mathrm{mL}$ in cold PBS and permeabilized with methanol at $-20{ }^{\circ} \mathrm{C}$ (Labsynth) and incubated with $10 \mu \mathrm{g} / \mathrm{mL}$ of Rh123 (Sigma-Aldrich) for $30 \mathrm{~min}$ at $37^{\circ} \mathrm{C}$ in the dark. For fluorescence-activated cell sorter (FACS) analysis, 30,000 events for each sample were acquired in the FACSCANTO II system (BD Biosciences), at wavelengths of $488 \mathrm{~nm}$ for excitation and $525 \mathrm{~nm}$ for emission as proposed by Li et al. [35]. The analysis was performed using Flowjo 7.6.4 software (Treestar Ashland, USA).

\section{Statistical analysis}

Values are presented as the means \pm standard deviation (SD) of three independent experiments, and statistical significance was set as a $p$ value less than 0.05 . Significance was determined by analysis of variance followed by the Dunnett's or Bonferroni post-hoc test (GraphPad Prism 5.0 program).

\section{Abbreviations}

SOD: Superoxide dismutase; DPPH: 2,2-diphenyl-1-picrylhydrazyl; ROS: Reactive oxygen species; EAT: Ehrlich ascites tumor; GSH: Glutathione; DMSO: Dimethyl sulfoxide; DMEM: Dulbecco's modified Eagle's medium; FBS: Fetal bovine serum; PBS: Phosphate balanced salt solution; HEPES: 4-(2-hydroxyethyl)-1piperazineethanesulfonic acid; EGTA: Ethylene glycol tetraacetic acid; EDTA: Ethylene diamine tetraacetic acid; CAT: Catalase; LPO: Lipid hydroperoxide; EIA: Enzyme immunoassay; 8-Isoprostanes: (8-iso PGF2a); SDS: Sodium dodecyl sulfate; DNPH: 2,4-Dinitrophenylhydrazine; PGF2a: Prostaglandin F2 alpha; EC-SOD: Extracellular superoxide dismutase; GPx: Gluthatione peroxidase.

\section{Competing interests}

The authors declare that they have no competing interests.

\section{Authors' contributions}

AMSL, JDFQ and TKSL developed the experimental assays and data analysis; LFAL and AMSL conceived of the study, participated in its design and data analysis and helped to draft the manuscript; SRBM participated in data analysis and helped to draft the manuscript. All authors read and approved the final manuscript.

\section{Acknowledgments}

This work was supported by the Conselho Nacional de Desenvolvimento Científico e Tecnológico (CNPq). We thank Dr. Carlos Frederico Martins Menck (ICB-USP, Brazil) who kindly provided the cell lines used in this study and Dr. Regina Vasconcellos Antonio (BQM-UFSC, Brazil) for kindly providing the purified violacein.

\section{Author details}

1Departamento de Biologia Celular e Genética, Universidade Federal do Rio Grande do Norte, CEP 59072-970, Natal, RN, Brazil. ²Departamento de Biologia Celular e Molecular, Centro de Biotecnologia, Universidade Federal da Paraíba, CEP 58051-900, João Pessoa, PB, Brazil.

Received: 30 September 2014 Accepted: 27 May 2015

Published online: 06 June 2015

\section{References}

1. Subramaniam S, Ravi V, Sivasubramanian A. Synergistic antimicrobial profiling of violacein with commercial antibiotics against pathogenic micro-organisms. Pharm Biol. 2014;52:86-90.

2. Cazoto LL, Martins D, Ribeiro MG, Durán N, Nakazato G. Antibacterial activity of violacein against Staphylococcus aureus isolated from bovine mastitis. J Antibiot (Tokyo). 2011;64:395-7.

3. Berni E, Marcato PD, Nakazato G, Kobayashi RKT, Vacchi FI, Umbuzeiro GA, et al. Violacein/poly( $\varepsilon$-caprolactone)/chitosan nanoparticles against bovine mastitis: Antibacterial and ecotoxicity evaluation. J Phys: ConfSer. 2013;429:012030.

4. Melo PS, Maria SS, Vidal BC, Haun M, Durán N. Violacein cytotoxicity and induction of apoptosis in V79 cells. In Vitro Cell Dev Biol Anim. 2000;36:539-43.

5. Bromberg N, Dreyfuss JL, Regatieri CV, Palladino MV, Durán N, Nader HB, et al. Growth inhibition and pro-apoptotic activity of violacein in Ehrlich ascites tumor. Chem Biol Interact. 2010;186:43-52.

6. Queiroz KC, Milani R, Ruela-de-Sousa RR, Fuhler GM, Justo GZ, Zambuzzi WF, et al. Violacein induces deathof resistant leukaemia cells via kinome reprogramming, endoplasmic reticulumstress and Golgi apparatus collapse. PLoS One. 2012;7:e45362.

7. Leon LL, Miranda CC, De Souza AO, Durán N. Antileishmanial activity of the violacein extracted from Chromobacteriumviolaceum. J Antimicrob Chemother. 2001;48:449-50.

8. May G, Brummer B, Ott H. Treatment of prophylaxis of polio and herpes virus infections comprises admin. of 3-(1,2-dihydro-5-(5-hydroxy-1H- indol-3-yl)-2-oxo3H-pyrrole-3-ylidene)-1,3-dihydro-2H-indol-2-one. GerOffenDE 1991, 3935066.

9. Andrighetti-Fröhner CR, Antonio RV, Creczynski-Pasa TB, Barardi CR, Simões CM. Cytotoxicity and potential antiviral evaluation of violacein produced by Chromobacteriumviolaceum. Mem Inst Oswaldo Cruz. 2003;98:843-8.

10. Durán N, Antonio RV, Haun M, Pilli RA. Biosynthesis of a trypanocide by Chromobacteriumviolaceum. World J Microbiol Biotechno. 1994;10:686-90.

11. Matz C, Webb JS, Schupp PJ, Phang SY, Penesyan A, Egan S, et al. Marine biofilm bacteria evade eukaryotic predation by targeted chemical defense. PLoS One. 2008;3:e2744. 
12. Lopes SC, Blanco YC, Justo GZ, Nogueira PA, Rodrigues FL, Goelnitz U, et al. Violacein extracted from Chromobacteriumviolaceum inhibits Plasmodium growth in vitro and in vivo. Antimicrob Agents Chemother. 2009;53:2149-52.

13. Antonisamy $\mathrm{P}$, Ignacimuthu S. Immunomodulatory, analgesic and antipyretic effects of violacein isolated from Chromobacteriumviolaceum. Phytomedicine. 2010;17:300-4.

14. Antonisamy $P$, Kannan $P$, Ignacimuthu S. Anti-diarrhoeal and ulcer-protective effects of violacein isolated from Chromobacteriumviolaceum in Wistar rats. Fundam Clin Pharmacol. 2009;23:483-90.

15. Konzen M, De Marco D, Cordova CA, Vieira TO, Antônio RV, Creczynski-Pasa TB. Antioxidant properties of violacein: possible relation on its biological function. Bioorg Med Chem. 2006;14:8307-13.

16. de Carvalho DD, Costa FT, Duran N, Haun M. Cytotoxic activity of violacein in human colon cancer cells. Toxicol In Vitro. 2006;20:1514-21.

17. Arur S, Uche UE, Rezaul K, Fong M, Scranton V, Cowan AE, et al. Annexin I is an endogenous ligand that mediates apoptotic cell engulfment. Dev Cell. 2003:4:587-98.

18. Wlodkowic D, Telford W, Skommer J, Darzynkiewicz Z. Apoptosis and beyond: cytometry in studies of programmed cell death. Methods Cell Biol. 2011;103:55-98.

19. Bromberg N, Justo GZ, Haun M, Durán N, Ferreira CV. Violacein cytotoxicity on human blood lymphocytes and effect on phosphatases. J Enzyme Inhib Med Chem. 2005;20:449-54.

20. Saraiva VS, Marshall JC, Cools-Lartigue J, Burnier Jr MN. Cytotoxic effects of violacein in human uveal melanoma cell lines. Melanoma Res. 2004;14:421-4.

21. Matés JM. Effects of antioxidant enzymes in the molecular control of reactive oxygen species toxicology. Toxicology. 2000;153:83-104.

22. Franco-Molina MA, Mendoza-Gamboa E, Sierra-Rivera CA, Gómez-Flores RA, Zapata-Benavides P, Castillo-Tello P, et al. Antitumor activity of colloidal silver on MCF-7 human breast cancer cells. J Exp Clin Cancer Res. 2010;29:148.

23. Mojib N, Nasti TH, Andersen DT, Attigada VR, Hoover RB, Yusuf N, et al. The antiproliferative function of violacein-like purple violet pigment (PVP) from an Antarctic Janthinobacterium sp. Ant5-2 in UV-induced 2237 fibrosarcoma. Int J Dermatol. 2011;50:1223-33.

24. Melo PS, de Azevedo MM, Frungillo L, Anazetti MC, Marcato PD, Durán N. Nanocytotoxicity: violacein and violacein-loaded poly (D, L-lactide-co-glycolide) nanoparticles acting on human leukemic cells. J Biomed Nanotechnol. 2009;5:192-201.

25. Ferreira CV, Bos CL, Versteeg HH, Justo GZ, Durán N, Peppelenbosch MP. Molecular mechanism of violacein-mediated human leukemia cell death. Blood. 2004;104:1459-64.

26. Ly JD, Grubb DR, Lawen A. The mitochondrial membrane potential (deltapsi(m))in apoptosis; an update. Apoptosis. 2003;8:115-28.

27. Perl A, Gergely Jr P, Nagy G, Koncz A, Banki K. Mitochondria hyperpolarization: a checkpoint of T-cell life, death and autoimmunity. Trends Immunol. 2004:25:360-7.

28. Banki K, Hutter E, Gonchoroff NJ, Perl A. Elevation of mitochondrial transmembrane potential and reactive oxygen intermediate levels are early events and occur independently from activation of caspases in Fassignaling. J Immunol. 1999;162(3):1466-79.

29. VandenBerghe T, Vanlangenakker N, Parthoens E, Deckers W, Devos M, Festjens $\mathrm{N}$, et al. Necroptosis, necrosis and secondary necrosis converge on similar cellular disintegration features. Cell Death Differ. 2010;6:922-30.

30. Rettori D, Duran N. Production, extraction and purification of violacein: an antibiotic pigment producedby Chromobacteriumviolaceum. World J Microbiol Biotechnol. 1998;14:685-8.

31. Kaltenbach JP, Kaltenbach MH, Lyons WB. Nigrosin as a dye for differentiating live and dead ascites cells. Exp Cell Res. 1958;15:112-7.

32. Bradford MM. A rapid and sensitive method for the quantitation of microgram quantities of protein utilizing the principle of protein-dye binding. Anal Biochem. 1976;72:248-54.

33. Petta TB, Nakajima S, Zlatanou A, Despras E, Couve-Privat S, Ishchenko A, et al. Human DNA polymerase iota protects cells against oxidative stress. EMBO J. 2008:27:2883-95.

34. Hawkins CL, Morgan PE, Davies MJ. Quantification of protein modification by oxidants. Free Radic Biol Med. 2009;46:965-88,

35. Li JJ, Tang $Q, L i Y, H u B R$, Ming ZY, Fu Q, et al. Role of oxidative stress in the apoptosis of hepatocellular carcinoma induced by combination of arsenic trioxide and ascorbic acid. Acta Pharmacol Sin. 2006;27:1078-84.

\section{Submit your next manuscript to BioMed Central and take full advantage of:}

- Convenient online submission

- Thorough peer review

- No space constraints or color figure charges

- Immediate publication on acceptance

- Inclusion in PubMed, CAS, Scopus and Google Scholar

- Research which is freely available for redistribution

Submit your manuscript at www.biomedcentral.com/submit 